\title{
燃焼ガス䨌囲気下における各種混合塩の腐食性 について*
}

\author{
P.D. Miller**, H.H. Krause**, J. Zupan*** \\ \& W.K. Boyd**
}

\section{概 要}

実験室的研究で, 各種混合塩の存在下における $316 \sim$ $538^{\circ} \mathrm{C}\left(600 \sim 1,000^{\circ} \mathrm{F}\right)$ の温度領域の合成燃焼ガス雾囲気 に鋼を暴露した。混合硫酸塩に塩化物を添加すると，腐 食は非常に促進され, 特に $538^{\circ} \mathrm{C}$ で著しいことが判明し た。 $316^{\circ} \mathrm{C}$ で，硫酸水素塩 (bisulfate) やピ口硫酸塩 (pyrosulfate) のようなイオウを含んでいる塩には非常 に简食性がある。都市ごみ焼却炉の火炎側の窗食におけ る材料の重要性について議論した。

1969 年以来, 焼却炉の腐食に関する実環境ならびに実 験室的研究が, 米国環境保護庁公衆衛生局固体廃棄物管 理部 (The Solid Waste Management Office, U.S. Public Health Service, Environmental Protection Agency) の財政的援助の下に, Battell-Columbus 研究 所で実施されている。主要な興味は比較的新しい型式の 都市ごみ焼却炉において焼却の熱を吸収するための炉壁 の水冷管と対流経路に生じる腐食の一層の理解にあっ た。この研究の目的は腐食の程度を把握し, 原因を解明 するとともに伶食を軽減する方法を工夫することであ る。前報1 で述べた実環境での研究の結果, この系で生 じうる腐食が苛酷なものであることが立証された。また この研究は侵食の原因としての有効な情報をもたらし た。たとえば，焼却炉の砱食プローブの付着物中に塩素 やイオウを含んだ塩がしばしば見いだされることが判明 した。同じプローブの腐食した表面の EPMA 分析で, これらの塩が下地金属のごく近傍に存在することが明ら かになった。このように，窝食の見地からこれらの塩が 重要な役割を果していると思われる。

火力発電所に関する研究によれば, 石炭中の塩素は窝 食過程に执いて促進的作用をすることが十分示されてい

* 訳者: 酒井潤一 (日本鋼管株式会社技術研究所)

** Battelle-Calumbus Laboratories, Columbus, $\mathrm{OH}$.

*** Chemical Abstract Services, The Ohio State University, Columbus, $\mathrm{OH}$.

(原文) Corrosive Effects of Various Salt Mixtures Under Combustion Gas Atmospheres. Corrosion, Vol. 28, No. 6, 222 225 (1972).
る。硫酸塩一塩化物混合塩中における窗食に関するいく つかの研究 ${ }^{2 \sim 5)}$ が報告されている。しかし，多くの報告 されている研究は $538^{\circ} \mathrm{C}$ 以上の温度に扔いて炭素鋼より むしろ合金鋼についてなされている。

水冷管炉壁の焼却炉の操業は低温領域が問題となるの で，実験室的研究は炭素鋼に着目して $538^{\circ} \mathrm{C}$ 打よびそれ 以下の温度で，イオウと塩素を含む塩混合物の窗食機構 の解明を試みた。しかし，321 型ステンレス鋼について 研究した。この研究では主に塩素とイオウの役割につ いて議論してきたが，前述の実環境試験の結果では，腐 食個所の近傍の化合物は, 鉛, 覀鉛, カリウム, そして 時にはスズをも含んでいたことを述べて抢くべきであろ ろ。NACE に投稿した前報に水冷管炉壁型焼却炉 の窝 食を説明するための可能性のある機構について詳細に述 べてある。

すでに述べた研究でとられた手法は既知の塩混合物と 直接接している状態扔よび接していない状態で合金を合 成燃焼ガスに暴露するものである。生じた腐食の程度の 評価は重量減少によった。

\section{装置と方法}

金属試験片は抵抗加熱管状炉に入れた石英または Vycor 管中の磁性ボートあるいはルツボ中に置かれた。ガ スは熱伝達をよくするために石英綿を充填した予熱域で 予熱した。

焼却炉で認められる $\mathrm{CO}_{2}$ ，空気， $\mathrm{SO}_{2}$ 抢よび水からな る典型的な混合物で構成する合成燃燒ガス (F. G.) が用 いられた。用いた標準組成は $250 \mathrm{ppm} の \mathrm{SO}_{2}$ を含む 80 $\%$ 空気， $10 \% \mathrm{CU}_{2}$ 抢よび $10 \%$ 水である。ガス量は毎分 約 $4.6 l$ で, これは線速度として $0.5 \mathrm{ft} / \mathrm{sec}$ に対応する。 反応器に至るまでの装置は, 反応器への炭酸ガスおよ び空気量測定用の流量計, これら二つのガスを $19.7 \mathrm{psia}$ に制御するマノメーター, および系と装置出口部ての圧 力損失を測定するためのマノメーターからなる。制御さ れた少量の $\mathrm{SO}_{2}$ は毛細管を通じて炭酸ガスの流れに混合 した。 $\mathrm{SO}_{2}$ の量は定期的に過酸化水素法で求め, チェッ クした。加熱水中に空気を通すことにより水蒸気を系に 
表 1 供 試 鋼 の 組 成

\begin{tabular}{|c|c|c|c|}
\hline & & 成 & (wt $\%)$ \\
\hline & A106 グレード B & A $213-\mathrm{T} 11$ & 321 型 ステンレス鋼 \\
\hline 炭 素（最大） & 0.30 & 0.15 & 0.08 (最大) \\
\hline マンガン & $0.29 \sim 1.06$ & $0.30 \sim 0.60$ & 2.00 (最大) \\
\hline リ ン（最 大） & 0.048 & 0.030 & 0.030 \\
\hline イオウ (最大) & 0.058 & 0.030 & 0.030 \\
\hline シリコン (最小) & 0.10 & $0.50 \sim 1.00$ & 0.75 (最大) \\
\hline ク口ム & - & $1.00 \sim 1.50$ & $1.70 \sim 20.0$ \\
\hline モリブデン & - & $0.44 \sim 0.65$ & - \\
\hline ニッケル & - & - & $9.00 \sim 13.0$ \\
\hline チタン & - & - & 最小で炭素の 5 倍 \\
\hline
\end{tabular}

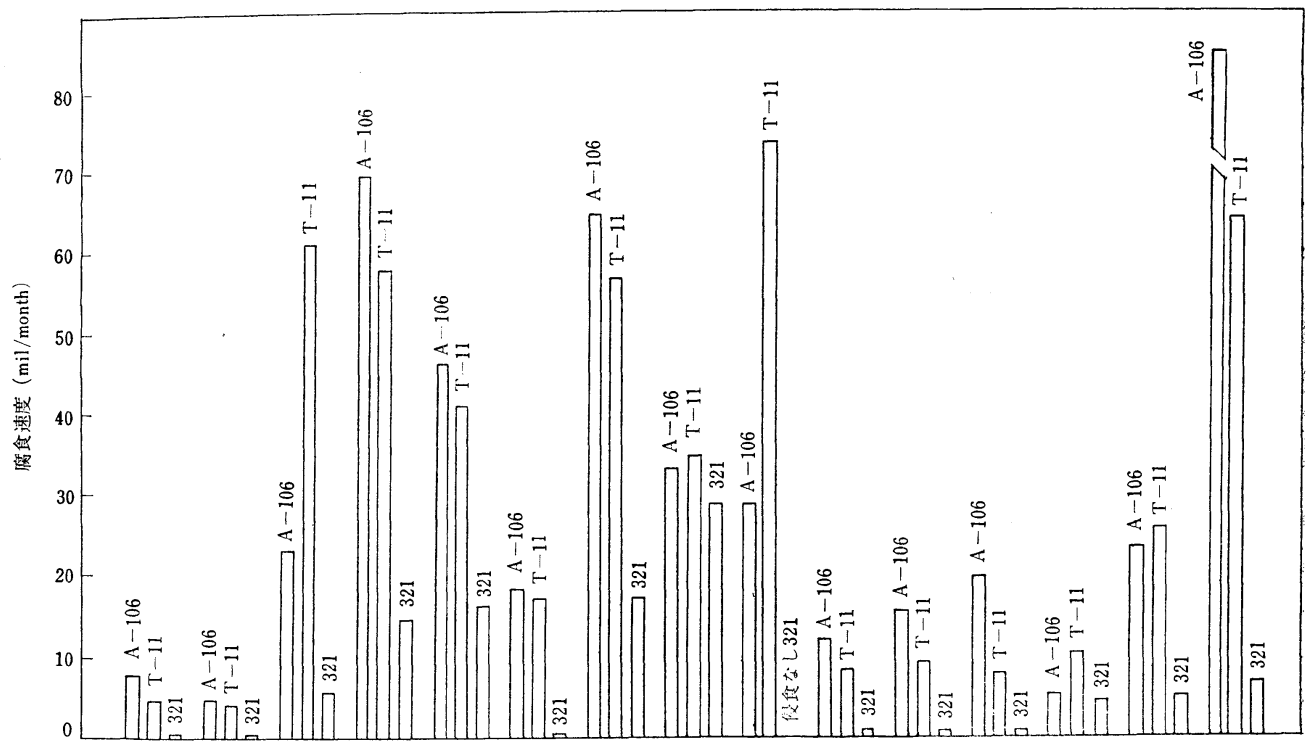

\begin{tabular}{|c|c|c|c|c|c|c|c|c|c|c|c|c|c|c|c|}
\hline 実験 No. & 0 & 3 & 1 & 5 & 20 & 7 & 10 & 11 & 13 & 15 & 16 & 18 & 17 & 19 & 21 \\
\hline $\mathrm{K}_{2} \mathrm{SO}_{4} \%$ & - & 59 & 58 & 78 & 78 & 99 & 75 & 75 & - & - & 78 & 78 & 78 & 78 & 75 \\
\hline $\mathrm{Na}_{2} \mathrm{SO}_{4} \%$ & - & 16 & 16 & 21 & 21 & - & 20 & 20 & - & - & 21 & 21 & 21 & 21 & 20 \\
\hline $\mathrm{NaCl} \%$ & - & - & 1 & 1 & 1 & 1 & 5 & - & 100 & 100 & 1 & 1 & 1 & 1 & 5 \\
\hline その他％ & - & $\begin{array}{c}25 \mathrm{Fe}_{2} \\
\mathrm{O}_{3}\end{array}$ & $\begin{array}{c}25 \mathrm{Fe}_{2} \\
\mathrm{O}_{3}\end{array}$ & - & - & - & - & $5 \mathrm{KCl}$ & - & - & - & - & - & - & - \\
\hline 雲囲気 & F.G. & F.G. & F.G. & F. G. & F. G. & F. G. & F.G. & F.G. & F. G. & $\begin{array}{l}\mathrm{SO}_{2} \\
\text { なし }\end{array}$ & $\begin{array}{l}\mathrm{SO}_{2} \\
\text { なし }\end{array}$ & $\begin{array}{l}\mathrm{SO}_{2} \\
\text { なし }\end{array}$ & $\mathrm{He}$ & $\begin{array}{l}\mathrm{He}+ \\
\mathrm{SO}_{2} \\
\end{array}$ & $\begin{array}{l}\mathrm{H} \cdot \mathrm{G} . \\
\text { 高 } \\
\end{array}$ \\
\hline
\end{tabular}

アジト・テスト -

図 $1538^{\circ} \mathrm{C}$ の各種条件下での鋼の腐食量

燃焼ガス (F.G.) : $80 \%$ 空気, $10 \% \mathrm{CO}_{2}, 10 \%$ 水および $250 \mathrm{ppm} \mathrm{SO}_{2}$, 試験時間 : 50 時間

導入し，その量は空気量と貯水槽の温度で制御した。

$0.75 \times 0.175 \times 0.125$ in の腐食試験片を A 106-B， A 213-T 11 および 321 型ステンレス鋼から作成した。表 1 にこれら合金の公称組成を示す。

暴露時間は通常 50 時間で, 炭食量は重量変化測定と 検鏡試験で評価した。腐食した試験片上の硫化物の検出
には Szymanski6) が報告しているナトリウム・アジド・ テスト (sodium azide test) を用いた。

$538^{\circ} \mathrm{C}\left(1,000^{\circ} \mathrm{F}\right)$ における腐食結果

$538^{\circ} \mathrm{C}$ における研究の大部分はモル分率て $3: 1$ の $\mathrm{K}_{2} \mathrm{SO}_{4}$ と $\mathrm{Na}_{2} \mathrm{SO}_{4}$ からなる基本的な混合塩で実施した。 $538^{\circ} \mathrm{C}$ に打ける窝食速度に対する混合塩組成とガス雾 


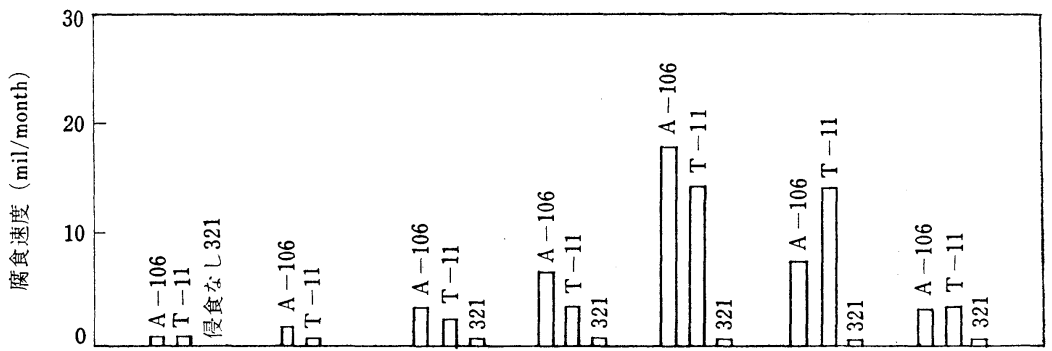

\begin{tabular}{lccccccc} 
実験 No. & 0 & 8 & 4 & 6 & 9 & 12 & 14 \\
\hline $\mathrm{K}_{2} \mathrm{SO}_{4} \%$ & - & 78 & 58 & 78 & 75 & 75 & - \\
$\mathrm{Na}_{2} \mathrm{SO}_{4} \%$ & - & 21 & 16 & 21 & 20 & 20 & - \\
$\mathrm{NaCl} \%$ & - & - & 1 & 1 & 5 & $5 \mathrm{KCl}$ & 100 \\
その他 \% & - & - & $25 \mathrm{Fe}_{2} \mathrm{O}_{3}$ & - & - & - & - \\
\hline
\end{tabular}

図 $2427^{\circ} \mathrm{C}$ の各種条件下での腐食量

燃焼ガス: $80 \%$ 空気, $10 \% \mathrm{CO}_{2}, 10 \%$ 水および $250 \mathrm{ppm} \mathrm{SO}_{2}$, 試験時間： 50 時間

囲気の詳細な条件を図 1 にまとめた。またここ図の下 の線は腐食した金属上の硫化物の存在に対するアジド・ テストの結果を示している。++十の三重記号は試験の 結果硫化物が非常に多いことを示している。䆚食度は 50 時間の暴露による重量減少から外挿し計算して mil/ month の単位で示した。

図1からわかるように, 実験 3 で用いた $\mathrm{Fe}_{2} \mathrm{O}_{3}$ を含む $\mathrm{K}_{2} \mathrm{SO}_{4}-\mathrm{Na}_{2} \mathrm{SO}_{4}$ 混合塩は燃焼ガスのみ（実験 0 ）の結果 に比べて腐食を促進しなかった。しかし $1 \%$ の NaCl を 加えると実験 $1,5,20$ に示すように腐食は著しく増大し た。実験 5 と 20 は繰り返し試験でかなりよい再現性を 示している。

Alkali iron trisulfate が反応によって形成されるか否 かを調べるために $\mathrm{Fe}_{2} \mathrm{O}_{3}$ を添加した。これらの化合物は $593^{\circ} \mathrm{C}\left(1,100^{\circ} \mathrm{F}\right)$ で窗食性があることが知られている。 $\mathrm{Fe}_{2} \mathrm{O}_{3}$ の添加は盛食を促進しなかったので, 混合塩ある いはナトリウムやカリウムの硫酸塩, 酸化鉄, $\mathrm{SO}_{3}$ など からの alkali-metal ferric trisulfate の生成はこの温度 領域では主因子ではないと結論される。

実験 7 からわかるように，1\% $\mathrm{NaCl}$ を含む $\mathrm{K}_{2} \mathrm{SO}_{4}$ は $\mathrm{NaCl}$ を含む $\mathrm{K}_{2} \mathrm{SO}_{4}-\mathrm{Na}_{2} \mathrm{SO}_{4}$ 混合塩より腐食性にそし W。

$\mathrm{A} 106$ および $\mathrm{T} 11$ に対する $5 \%$ 程度の $\mathrm{KCl}$ の窗食性

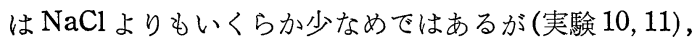
塩化物の含有量の増加はほとんど効果がない。

実験 13 で得られたように, 燃焼ガスと塩化ナトリウム だけでも炭素鋼に対して非常に腐食性があることは意味 深いものである。この試験片からアジド・テストの結果 硫化物が検出されたことはより大きな意味をもつ。この ように, 燃焼ガス中の $\mathrm{SO}_{2}$ が唯一のイオウ源であること
を考えると,この $\mathrm{SO}_{2}$ の関与する何らかの反応が重要に なる。もちろん，これまでの試験のうち腐食したものは いずれも硫化物が検出されている。また，简食量と検出 された硫化物の間には相関がある。

イオウと $\mathrm{SO}_{2}$ の関与する可能な反応をより一層把握中 るために $\mathrm{SO}_{2}$ を除いたいくつかの試験を実施した。さら に実験 21 では燃焼ガス中の $\mathrm{SO}_{2}$ の含有量を $250 \mathrm{ppm}$ か ら $2,500 \mathrm{ppm}$ に増加させた。

実験 15,16 および 18 からわかるように, 燃焼ガスか ら $\mathrm{SO}_{2}$ を除くと塩化物単独および硫酸塩一塩化物混合物 による窗食は著しく減少する。実験 16 と 18 は繰り返し 実験で，結果は非常によい一致を示していることがわか る。これらの $\mathrm{SO}_{2}$ のない三つの実験では試料の金属表面 に硫化物が検出されなかったことは重要である。

同様に， $\mathrm{SO}_{2}$ を含まないへリウム中に暴露した結果 (実験 17), 腐食量は少なく硫化物は形成しなかった。へ リウムに $\mathrm{SO}_{2}$ を添加すると $(2,500 \mathrm{ppm})$ 実験 19 に示す ように敕食は数倍増加した。この実験の試験片上にも硫 化物は検出されなかった。

$2,500 \mathrm{ppm}$ の $\mathrm{SO}_{2}$ を含む合成燃焼ガスに打ける実験で は $\mathrm{A} 106$ 鋼に打いてわずかながら简食速度の増加が認め られたが，T11 鋼の窗食速度は燃焼ガス中の $\mathrm{SO}_{2}$ が 250 ppm（実験 10）の場合と同等であった。

\section{$427^{\circ} \mathrm{C}\left(800^{\circ} \mathrm{F}\right)$ における腐食結果}

既に述べた $538^{\circ} \mathrm{C}\left(1,000^{\circ} \mathrm{F}\right)$ と同じ条件て $427^{\circ} \mathrm{C}$ 『 7 回の実験を行なった。結果は図 2 にまとめた。一般に腐 食速度は $538^{\circ} \mathrm{C}$ に比較して非常に遅いが， $\mathrm{NaCl}$ による 促進効果が認められた。この温度では $\mathrm{SO}_{2}$ 量の変化によ る効果は研究しなかった。

321 型ステンレス鋼は $538^{\circ} \mathrm{C}$ で実施したいくつかの実 


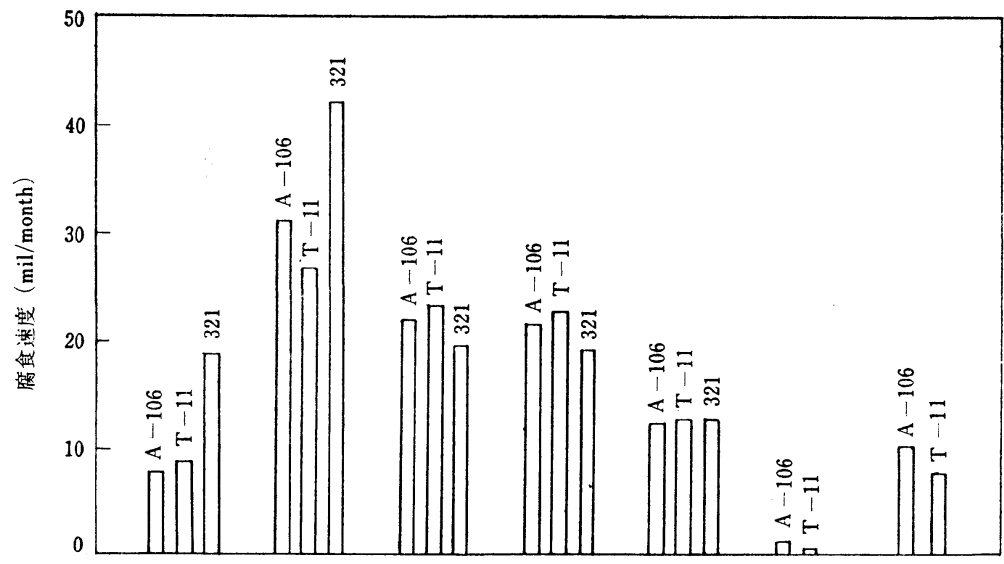

\begin{tabular}{lrrrrrrr} 
実験 $\mathrm{No}$ & 48 & 50 & 57 & 59 & 58 & 52 & 55 \\
\hline $\mathrm{KHSO}_{4} \%$ & 100 & 95 & 90 & 90 & 80 & 50 & 50 \\
$\mathrm{NaCl} \%$ & - & 5 & 5 & 5 & 10 & 5 & 5 \\
$\mathrm{ZnCl}_{2} \%$ & - & - & 5 & 5 & 10 & - & 30 \\
その他\% & - & - & - & - & - & $30 \mathrm{ZnSO}_{4}$ & $15 \mathrm{PbCl}_{2}$ \\
その他\% & - & - & - & - & - & $15 \mathrm{PbO}^{2}$ & - \\
$\mathrm{SO}_{2} \mathrm{ppm}$ & 250 & 250 & 250 & 250 & 250 & 250 & 250 \\
$\mathrm{HCl} \mathrm{ppm}$ & - & - & - & 2,000 & - & - & - \\
\hline アシド・テスト & + & +++ & +++ & +++ & +++ & +++ & +++ \\
物理的状態 & 溶融 & 溶融 & 溶融 & 溶融 & 溶融 & 溶融 & 一部溶融
\end{tabular}

図 $3316^{\circ} \mathrm{C}$ の窗食に及ぼす $\mathrm{KHSO}_{4}$ の効果

験で腐食したが $427^{\circ} \mathrm{C}$ では窗食は認められなかった。 $427^{\circ} \mathrm{C}$ におけるアルカリ金属塩化物添加および然焼ガス 中の $\mathrm{SO}_{2}$ の存在の効果は $538^{\circ} \mathrm{C}$ に打ける炭素鋼の場合と 一般に同じであった。 $427^{\circ} \mathrm{C}$ に抢ける $5 \%$ 程度の $\mathrm{KCl}$ と $\mathrm{NaCl}$ の腐食性は $538^{\circ} \mathrm{C}$ と比較して少ない。

\section{$316^{\circ} \mathrm{C}\left(600^{\circ} \mathrm{F}\right)$ における腐食結果}

実環境での試験によって火炎側での窝食は金属の温度 が $316^{\circ} \mathrm{C}$ 执よびそれ以下で起こることがわかっているの で, 各種塩組成にわたる広範囲の実験室試験を実施した。 標準合成燃焼ガスを用い, いくつかの実験では $\mathrm{HCl}$ を添 加した。

$316^{\circ} \mathrm{C}$ の試験で最先窗食性のあった塩は硫酸水菜塩と ピロ硫酸塩であった。これらは融点が低いことと，化石 燃料燃焼ボイラの低温ボイラ管の腐食において重要な存

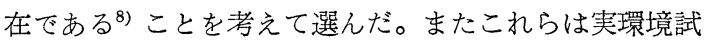
験で腐食部にイオウを含んだ塩が認められたことから腐 食促進物質であることが疑われる。

硫酸水素カリウム混合物の結果を図 3 の棒グラフにま とめた。実験 48 では $\mathrm{KHSO}_{4}$ のみでかなりの腐食が起 こり，ステンレス鋼は普通鋼より激しく零食することが 示された。ステンレス鋼のこのような腐食についての理 由は明らかでない。硫酸水素塩を含まない実験との比較 は図 4 の実験 22 を参照されたい。硫酸水素塩に $5 \%$ の
$\mathrm{NaCl}$ を添加すると简食は $3 \sim 4$ 倍增加する（実験 50 )。 $\mathrm{NaCl}$ とともに $5 \%$ あるいは $10 \%$ の $\mathrm{ZnCl}_{2}$ を添加して も窗食量に変化はない（実験 57,58 )。同じように燃焼 ガス中に $2,000 \mathrm{ppm}$ の $\mathrm{HCl}$ を含有させても窝食は促進 しない(実験 59)。 $\mathrm{NaCl}$-硫酸水素塩混合物に $\mathrm{ZnSO}_{4}$ と $\mathrm{PbO}$ を添加すると窝食は減少し(実験 52 ), また $\mathrm{PbCl}_{2}$, $\mathrm{ZnCl}_{2}$ を添加することによっても減少する(実験 55 )。し かし, $538^{\circ} \mathrm{C}$ では $\mathrm{PbCl}_{2}$ と $\mathrm{ZnCl}_{2}$ は窗食を促進すること を指摘しなければならない。

これらの実験を通じて混合塩はすべて溶融状態にあっ たこと，打よび腐食した金属から硫化物が検出されたこ とは注目されるべきである。

図4からわかるように， $\mathrm{K}_{2} \mathrm{~S}_{2} \mathrm{O}_{7}$ は炭素鋼およびステ ンレス鋼に対して $316^{\circ} \mathrm{C}$ で非常に窗食を促進する（実験 28）。しかし，腐食性のない化合物で希熎すると腐食は 著しく減少する。 $\mathrm{NaCl}$ の添加は否食をほとんど增大し ない(実験 44)。 $\mathrm{ZnCl}_{2}$ を添加するとステンレス鋼では やはり大きな腐食速度を示すが，炭素鋼の腐食は隇少す る(実験 36,41 )。他の酸化物，塩化物あるいは硫酸塩 の添加は $\mathrm{K}_{2} \mathrm{~S}_{2} \mathrm{O}_{7}$ の腐食性を減少させる（実験 46,40 , $30 ， 37)$ 。図 4 は上り窝食性の 混合物は実験中に溶融状 態になっていることを示している。

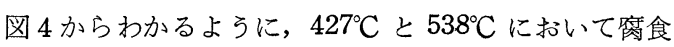




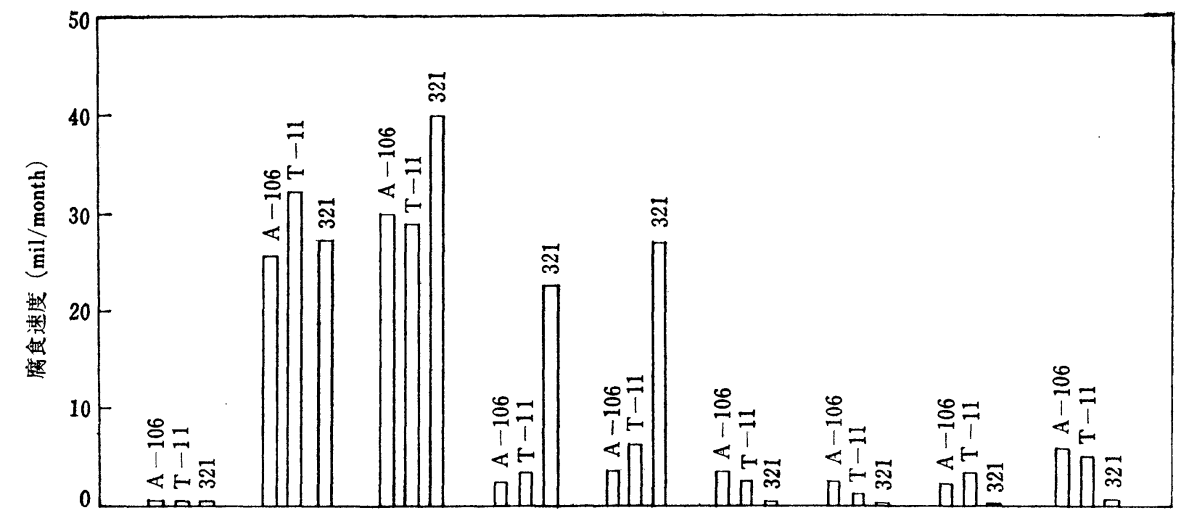

\begin{tabular}{lrrrrrrrrr}
\multicolumn{1}{c}{ 実験 No. } & 22 & 28 & 44 & 36 & 41 & 46 & 40 & 30 & 37 \\
\hline $\mathrm{K}_{2} \mathrm{~S}_{2} \mathrm{O}_{7} \%$ & - & 100 & 95 & 95 & 95 & 65 & 50 & 5 & 5 \\
$\mathrm{~K}_{2} \mathrm{SO}_{4} \%$ & 75 & - & - & - & - & - & - & 71 & 67 \\
$\mathrm{Na}_{2} \mathrm{SO}_{4} \%$ & 20 & - & - & - & - & - & - & 19 & 19 \\
$\mathrm{NaCl} \%$ & 5 & - & 5 & - & - & 5 & $\mathrm{ZnO}_{2} \mathrm{CaO}$ & 5 & 5 \\
$そ の$ 他 & - & - & - & $5 \mathrm{ZnC}_{2}$ & $5 \mathrm{ZnC}_{2}$ & $3) \mathrm{Fe}_{2} \mathrm{O}_{3}$ & $\mathrm{Al}_{2} \mathrm{O}_{3}$ & - & $5 \mathrm{ZnC}_{2}$ \\
\hline $\mathrm{SO}_{2} \mathrm{ppm}$ & 250 & 250 & 250 & 250 & 250 & 250 & 250 & 250 & 250 \\
$\mathrm{HCl} \mathrm{ppm}$ & - & - & - & - & - & - & 2000 & - & 2000 \\
\hline アシド・テスト & + & +++ & +++ & +++ & +++ & +++ & +++ & + & +++ \\
物理的状態 & 塊状 & 溶融 & 溶融 & 溶融 & 溶融 & 塊状 & 炭化 & 炭化 & 炭化
\end{tabular}

図 $4316^{\circ} \mathrm{C}$ の窗食に及ぼす $\mathrm{K}_{2} \mathrm{~S}_{2} \mathrm{O}_{7}$ の効㪙

性のあった $5 \% \mathrm{NaCl}$ を含む $\mathrm{K}_{2} \mathrm{SO}_{4}-\mathrm{Na}_{2} \mathrm{SO}_{4}$ 混合物は $316^{\circ} \mathrm{C}, 50$ 時間の実験では大した腐食性を示さなかった (実験 22)。

\section{考 察}

前節で述べた実験結果は $427^{\circ} \mathrm{C}$ と $538^{\circ} \mathrm{C}$ では塩化物と $\mathrm{SO}_{2}$ が腐食反応に打いて重要な因子であり，おそらくは 相乗的な効果によるものであることを示している。した がって，この二つの因子がともに作用すると㫘食は個々 の作用による否食の和より一層激しいものになる。

塩化物 の存在下における $\mathrm{SO}_{2}$ の効果について考える と, 空気がある時の反応は次式に示すように金属表面の ごく近傍で直接 $\mathrm{HCl}$ を形成すると思われる：

$$
\begin{array}{r}
4 \mathrm{NaCl}+2 \mathrm{SO}_{2}+\mathrm{O}_{2}+2 \mathrm{H}_{2} \mathrm{O} \rightarrow \\
2 \mathrm{Na}_{2} \mathrm{SO}_{4}+4 \mathrm{HCl} \ldots \ldots \ldots \ldots . .
\end{array}
$$

次に,この生成した $\mathrm{HCl}$ は金属と反応して塩化鉄を形 成する：

$$
\mathrm{Fe}+2 \mathrm{HCl} \rightarrow \mathrm{FeCl}_{2}+\mathrm{H}_{2}
$$

このように, $\mathrm{SO}_{2}$ の作用は $\mathrm{NaCl}$ (塩化物) の存在と 一義的に関係するので，もしも一方が存在しなければそ の腐食性は減少する。

$538^{\circ} \mathrm{C}$ で行なわれた無酸素で $\mathrm{SO}_{2}$ を通じた実験 19 の 結果は空気の存在する実験 5,20 に比べて腐食が著しく 少なかったので (1)式の有効性を裏づけている。

$\mathrm{HCl}$ の生成に寄与することに加えて, 硫化物を含む窗
食生成物の形成に対するイオウの付加的な作用を説明す る必要がある。実環境ならびに実験室試験で，イオウは EPMA 分析とアジド・テストの結果腐食した金属の近 くに存在し，また常に付着物の中にあったという事実を 考えればこのような説明の必要性は大きい。奏環境で得 られた付着物の $\mathrm{X}$ 線回折の結果各種の硫酸塩, すなわち, $\mathrm{Na}_{2} \mathrm{SO}_{4},(\mathrm{Na}, \mathrm{K}) \mathrm{SO}_{4}, \mathrm{CaSO}_{4}, \mathrm{PbSO}_{4}, \mathrm{ZnSO}_{4}, 4 \mathrm{PbO}$. $\mathrm{PbSO}_{4}$ 打よび $\mathrm{K}_{2} \mathrm{~Pb}\left(\mathrm{SO}_{4}\right)_{2}$ などが同定された事実から, イオウの役割を説明することは複雑である。

液相の物質が金属表面と接していれば固体やガスが接 している場合より，腐食反応がかなり強められることは 多くの場合認められる。 $427^{\circ} \mathrm{C}$ と $538^{\circ} \mathrm{C}$ で前述した各 硫酸塩, あるいはまたそ存在が確認されていない塩の 複合した混合物から液相が形成されると想像される。次 のイオン反応式 (Hills? ${ }^{7}$ を見よ) は鉄の轱食を説明でき るであろう。

$$
\begin{array}{r}
\mathrm{SO}_{4}{ }^{2-}+3 \mathrm{Fe} \rightarrow 2 \mathrm{Fe}^{3+}+\mathrm{Fe}^{2+}+\mathrm{S}^{2-}+4 \mathrm{O}^{2-} \\
\cdots \cdots \cdots \cdots \cdots \cdots \cdots \cdots \cdots \cdots \cdots \cdots \cdots \cdots \cdots \cdots \cdots \cdots \cdots \cdots \\
\mathrm{SO}_{4}{ }^{2-}+4 \mathrm{Fe} \rightarrow 4 \mathrm{Fe}^{2+}+\mathrm{S}^{2-}+4 \mathrm{O}^{2-} \ldots \ldots \cdots \cdots
\end{array}
$$

さらに塩素は金属表面の不働態皮膜を破壞する性質を もっているので, この溶融物中に塩化物が溶け込めばこ のような反応は促進されることが考えられる。

$316^{\circ} \mathrm{C}$ に拈ける実験室試験の結果はたぶん $\mathrm{KHSO}_{4}$ や $\mathrm{K}_{2} \mathrm{~S}_{2} \mathrm{O}_{7}$ のような化合物はこの温度領域では腐食に関与. 
するイオウを含んでいる物質であることを示している。 この両方の化合物の溶融温度が比較的低いものであるこ とはこの低い温度領域で售食が激しいことを説明する。 もちろんこのような説明は以前からの石炭燃焼ボイラの 炉壁管の扁食に関する研究から予想されなかったもので

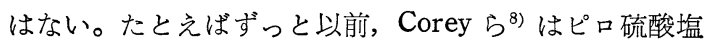
の腐食挙動について指摘し，反応を説明するために次式 を提案した：

$$
3 \mathrm{~K}_{2} \mathrm{~S}_{2} \mathrm{O}_{7}+\mathrm{Fe}_{2} \mathrm{O}_{3} \rightarrow 2 \mathrm{~K}_{3} \mathrm{Fe}\left(\mathrm{SO}_{4}\right)_{3}
$$

さらに彼らはもしも付着物の組成が $3 \mathrm{~K}_{2} \mathrm{SO}_{4} \cdot \mathrm{Na}_{2} \mathrm{SO}_{4}$ (グラセライト) ならば, $\mathrm{SO}_{3}$ 濃度が $7 \mathrm{ppm}$ 以上のとき 液相の硫酸塩は $279^{\circ} \mathrm{C}$ も低温で生成しうることを示し た。

燒却炉の付着物中にみられる複雑な化合物があるいは 前述した $279^{\circ} \mathrm{C} よ り$ 低温で液相を生成しうることは十分 考えられる。

次に塩化物の挙動に目をむけると，付着物に含まれる 塩化物の効果に関するこれらの実験室試験の結果は最近 報告された Cutler ら ${ }^{9)}$ の結果とよく一致していること が指摘されるべきであろう。彼らは塩化物の存在は常に 供試金属の促進された腐食の指標として考えうることを 示唆している。

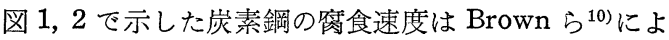
って報告されている塩化水素雾囲気下での炭素鋼の腐食 速度とかなりよく一致している。彼らは $427^{\circ} \mathrm{C}$ で简食 速度を約 $12 \mathrm{mil} / \mathrm{mo} ., 538^{\circ} \mathrm{C}$ のそれを約 $40 \mathrm{mil} / \mathrm{mo}$. と 報告している。このように塩化物の付着物による焼却炉 の窝食と式（1）（2）に概略した説明はかなり正当性が ある。焼却炉の壂食における塩化物の重要性に関するな お一層の事実は塩化物が腐食した金属表面と表面の付着 物中に認められることである。

さらに前報ではある条件下で焼却炉の付着物の下で遊 離塩素が形成され腐食に寄与することが示唆されてい る。

\section{謝辞}

The Solid Waste Management Office, EPA ヘのこ
の研究の勧告者である L. W. Lefke 氏と D. J. Keller 氏の協力と激励に対し深謝の意を表する。

また Ohio 州 Miami 郡, Virginia 州 Norfold, Navy Public Works Center, New York 州 Long Island, Hempstead 町 Oceanside の管理部と操業員の協力に感 謝する。

Battelle-Columbus の研究員である R. B. Engdahl, R.

D. Fischer, W.T. Reid, J.E. Reinoehl, E. J. Schulz, D. A. Vaughan, P.R. Webb 氏らの尽力に感謝する。

\section{引用 文 献}

1. Paul D. Miller and H. H. Krause. Factors Influencing the Corrosion of Boiler Steels in Municipal Incinerators, Corrosion, 27, 31 (1971).

2. R. J. Bishop and J. A. C. Samms. The Corrosion of Austenitic Superheater Steels by Alkali Sulfate/Chloride Mixtures in Air and in a Flue Gas Atmosphere, Arbeitsgemeinschaft Korrosion, 26th Event of the European Federation of Corrosion, Frankfurt, Germany (1965) April.

3. H. T. Shirley. Sulfate-Chloride Attack on High Alloy Steels and Nickel-Base Alloys, Proceedings of the Marchwood Conference, Mechanism of Corrosion by Fuel Impurities, edited by Johnston and Littler, Butterworths, London, pp. 617-628 (1963).

4. Patricia A. Alexander and Ruth A. Marsden. Corrosion of Superheater Materials by Residual Oil Ash, Proceedings of the Marchwood Conference, Mechanism of Corrosion by Fuel Impurities, edited by Johnston and Littler, Butterworths, London, pp. 542-555 (1963).

5. P. I. Fontaine and E. G. Richards. Hot Corrosion of NickelIron-Chromium-Cobalt Alloys by Sulfate-Chloride and SulfateVanadate Simulated Fuel Ashes, ASTM STP, 421, pp. 246-249 (1967).

6. Walter A. Szymanski. Method for Rapid Detection of Sulfur Embrittlement of Nickel, Materials Protection, 1, 100 (1962) September.

7. G. J. Hills. Corrosion of Metals by Molten Salts, Proceedings of the Marchwood Conference, Mechanism of Corrosion by Fuel Impurities, edited by Johnston and Littler, Butterworths, London, pp. 583-590 (1963).

8. R. C. Corey, H. A. Grabowski, and B. J. Cross. External Corrosion of Furnace Wall Tubes III. Further Data on Sulfate Deposits and the Significance of Iron Sulfide Deposits, Trans. Am. Soc. Mech. Eng., 71, 951 (1949).

9. A. J. B. Cutler, W. D. Halstead, J. W. Laxton, and C. G. Stevens. The Role of Chloride in the Corrosion Caused by Flue Gases and Their Deposits, ASME Preprint 70WA/CD-1, Annual Meeting, New York (1970) December.

10. M. H. Brown, W. B. DeLong, and J. R. Auld. Corrosion by Chlorine and by Hydrogen Chloride at High Temperatures, $J$. Ind. Eng. Chem., 39, 839 (1947). 